\title{
Aplikasi Dongeng Berbasis Text to Speech Untuk Platform Android
}

\author{
Uswatun Hasanah $^{1}$, Jaroji ${ }^{2}$ \\ Politeknik Negeri Bengkalis \\ Jl. Bathin Alam, Sungai Alam - Bengkalis - Riau, telp/fak. (+62766) 24566 \\ Email: ${ }^{1}$ uswatun.ti13b@student.polbeng.ac.id, ${ }^{2}$ jaroji@ polbeng.ac.id
}

\begin{abstract}
Abstrak
Anak-anak suka mendengarkan dongeng karena memberikan kesempatan kepada mereka untuk berimajinasi dengan menggambarkan peristiwa pada dongeng ke dalam khayalan. Dikarenakan banyak anak-anak menyukai dongeng, banyak peluang pengembangan aplikasi dongeng seperti menggunakan text to speech. Maka dari itu dilakukan pengembangan aplikasi dongeng menggunakan konsep Text to Speech untuk mengkonversikan text dongeng menjadi suara sebagai media pengganti membaca dongeng. Tujuan penelitian ini adalah untuk membuat aplikasi dongeng text to speech untuk platform android. Metode yang digunakan dalam penelitian ini ialah menggunakan metode waterfall.Aplikasi ini dirancang dengan menggunakan pemograman java dan editor eclipse. Data yang digunakan berupa teks dongeng dan pemanfaatan google text to speech untuk menghasilkan keluaran suara. Hasil akhir berupa aplikasi pada perangkat android, dan telah dilakukan pengujian. Hasil pengujian menunjukkan Aplikasi dongeng text to speech sudah mampu membaca dongeng, walaupun dari segi intonasi suara belum alami sebagai mana manusia membaca dongeng. Pengujian sistem dilakukan bahwa aplikasi ini hanya bisa digunakan pada perangkat android versi Lollipop (5.1.1) untuk menghasilkan keluaran suara bahasa Indonesia secara offline. Dari segi tampilan aplikasi, aplikasi ini belum Fleksibel sehingga hanya terlihat baik pada perangkat tertentu.
\end{abstract}

Kata kunci : Aplikasi, Dongeng, Text to Speech, Android

\begin{abstract}
Kids like hearing fable because it gives a chance for them to imagine by drawing an event into imagination. Since many kids like fable, there are many chances to create an application of fable that used text to speech. So from that, fable application text to speech is done to convert fable text into a voice as media of replacement from reading fable. The interest of kids is considered to emerge with this application in order to help parents easily in telling a fable to their kids. Parents are not necessary to tell the story by their voice. This application is planned by using java program and editor eclipse. The data used is fable text and Google text to speech to produce voice. The final result is an android application, and after being tested. The test result shown that Text to Speech application was be able to read a fable. The tested of application system is only can be used in android version 4.0.3 with online use. The android version Lollipop (5.1.1) to produce a voice output Indonesian offline. In term of display application, this application is not flexible so that only looks good on certain device.
\end{abstract}

Keyword: Application, Fable, Text to Speech, Android 


\section{Pendahuluan}

Dongeng adalah cerita yang berisi kisah-kisah menakutkan, seperti ibu tiri yang jahat, anak-anak yang dipanggang dalam oven, dan serigala yang buas. Meski demikian cerita-cerita tersebut disukai anak-anak karena memberikan kesempatan kepada anak untuk berimajinasi dengan menggambarkan peristiwa-peristiwa tersebut ke dalam khayalan (Ardini, 2012). Dengan demikian, dapat disimpulkan bahwa dongeng adalah cerita khayal baik itu dalam bentuk tertulis maupun oral yang sudah ada sejak dulu. Dongeng di sampaikan secara turuntemurun. Cerita dalam dongeng berkisah tentang kebaikan melawan kejahatan. Kisah dalam dongeng biasanya menceritakan tentang masyarakat, sejarah, fenomena alami dan perjuangan terhadap harapan untuk sebuah perubahan.

Dongeng merupakan cerita pengantar tidur untuk anak-anak. Cerita dongeng bersifat khayal, yang berarti tidak mungkin terjadi dalam kenyataan. Justru dengan bersifat khayal tersebut, dongeng dengan cepat memberikan khayalan kepada anak-anak untuk lebih merasuk ke alam mimpinya. Anak-anak biasanya masuk susah tidur, maka ayah-ibu, atau bahkan kakeknenek berdongeng untuk membuat anak/cucunya melenakan peristiwa-peristiwa tadi siang. Si Anak akan cepat tidur ketika dongeng selesai diceritakan. Lewat sebuah dongeng sebuah komunikasi dan kedekatan emosional dapat tercapai. Transfer nilai-nilai yang terkandung dalam sebuah dongeng dapat lebih mudah dimengerti.

Dikarenakan banyak anak-anak menyukai dongeng, banyak peluang pengembangan aplikasi dongeng yang dikemas menarik dan lebih praktis, seperti aplikasi cerita rakyat lokal bernama Dongeng berbasis iOS. Aplikasi Dongeng merupakan buku cerita rakyat digital yang berisikan 5 buah cerita rakyat local. Namun aplikasi ini membutuhkan alokasi memori yang besar (Santoso dkk, 2013). Serta banyak pengembangan aplikasi dongeng yang menggunakan audio rekaman untuk menghasilkan suara dongeng, namun aplikasi tersebut membutuhkan alokasi memori yang banyak untuk menyimpan audio.

Aplikasi dongeng juga bisa dikembangkan dengan menggunakan text to speech. Saat ini, kebutuhan teknologi untuk memenuhi tuntutan zaman semakin meningkat. Teknologi dikembangkan untuk lebih mempermudah setiap kegiatan manusia, terutama pada kecepatan dan keakuratan untuk mengimbangi setiap aktivitas manusia. Salah satunya yaitu memasukkan informasi ke komputer melalui ucapan dan mengonversi ucapan menjadi teks yang tersimpan di komputer. TTS (Text to Speech) merupakan suatu aplikasi dalam bidang teknologi bahasa, yang dapat mengkonversi teks dalam format suatu bahasa sehingga menjadi ucapan sesuai dengan pembacaan teks dalam bahasa yang digunakan (Pramadewi dkk, 2013).

Maka dari itu dilakukan pengembangan aplikasi dongeng menggunakan konsep Text to Speech untuk mengkonversikan teks dongeng menjadi suara sebagai media pengganti membaca dongeng. Tujuan penelitian ini adalah untuk membuat aplikasi dongeng text to speech yang dapat dijalankan pada platform Android. Dengan adanya aplikasi ini diharapkan dapat menimbulkan minat anak-anak terhadap dongeng dan membantu mempermudah orang tua dalam mendongeng kepada anaknya. Para orang tua tidak perlu lagi mendongeng sendiri dengan suaranya. Aplikasi ini dibuat dengan memanfaatkan library Google Text-to-Speech pada perangkat Android dengan didukung bahasa pemograman Java, dan Eclipse sebagai Integrated Development Environment (IDE) pengembang perangkat lunak. Intonasi Speech pada pembacaan dongeng dirancang berdasarkan tanda baca yang terdapat pada text dongeng. 


\section{Metode penelitian}

Metode yang digunakan dalam penelitian adalah metode waterfall. Metode waterfall merupakan metode yang digunakan terdiri atas analisa permasalahan, perancangan, penulisan kode program, dan pengujian (Pressman, 2011). Diagram dari metode waterfall dapat dilihat pada Gambar 1.

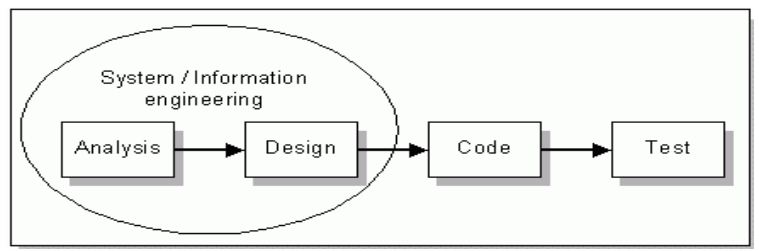

Gambar 1 Model Waterfall

(Sumber: Pressman, 2011)

1. Analisa Permasalahan, meliputi analisa sistem yang sedang berjalan dan sistem yang akan diusulkan. Data yang digunakan berupa text dongeng yang berasal dari website kumpulan dongen anak, dan hasil suara dongeng berasal dari library google text to speech.

2. Perancangan perangkat lunak, meliputi perancangan model proses menggunakan Unifed Modeling Language (UML) yaitu dengan Use Case Diagram dapat dilihat pada Gambar 2. Perancangan antar muka untuk tampilan aplikasi. Selain itu juga dilakukan perancangan antar muka aplikasi.

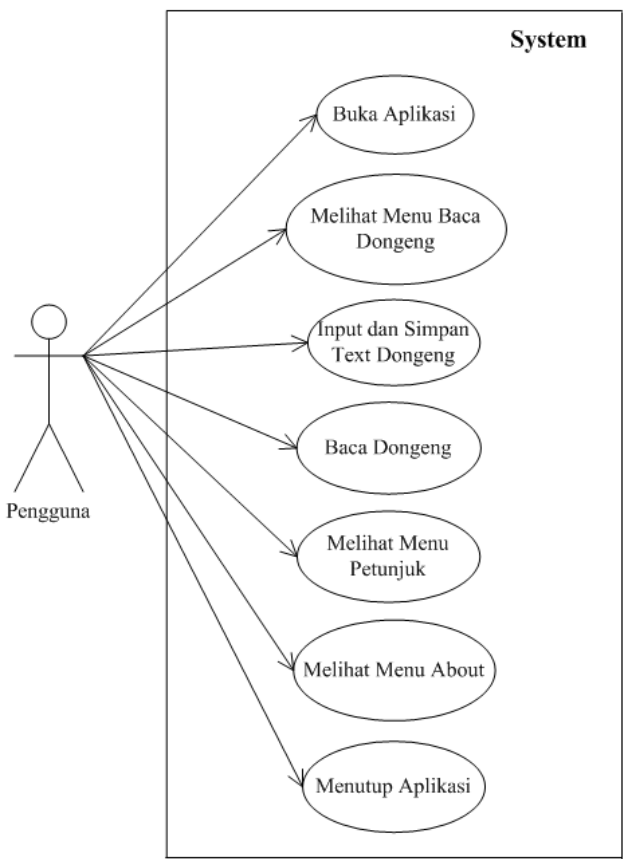

Gambar 2. Use Case

3. Penulisan kode Program, penulisan kode program dengan menggunakan bahasa pemograman java dengan editor Eclipse.

4. Pengujian, Pengujian aplikasi ini dilakukan untuk mengetahui layak tidaknya suatu aplikasi. Pengujian aplikasi ini dilakukan dengan dua tahapan, yaitu pengujian berdasarkan perbandingan suara dongeng audio dengan suara dongeng text to speech dan pengujian berdasarkan kesuaian antar muka pada beberapa perangkat android yang berbeda. 


\section{Hasil dan pembahasan}

Penelitian ini menghasilkan Aplikasi Dongeng Text To Speech berbasis Android yaitu aplikasi yang dapat mengubah teks dongeng menjadi suara sebagai media pengganti membaca dongeng. Aplikasi dirancang dengan menggunakan bahasa pemograman Java dan editor Eclipse. Intonasi suara yang diucapkan berdasarkan tanda baca pada teks. Dan hasil suara yang keluar berasal dari google text to speech. Untuk menghasilkan hasil suara dalam bahasa Indonesia aplikasi ini hanya dapat diinstal pada perangkat android yang memiliki fitur text to speech bahasa Indonesia.

Adapun antar muka untuk aplikasi Dongeng text to speech dapat dilihat pada Gambar 3 berikut.

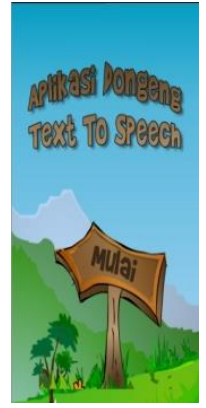

(a)

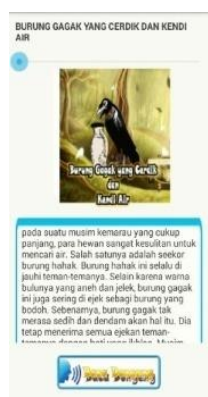

(d)

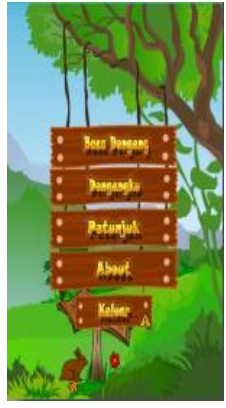

(b)

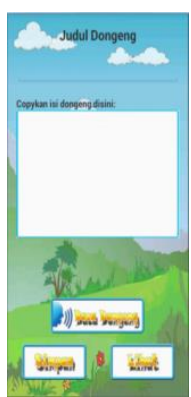

(e)

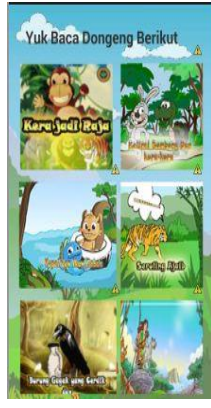

(c)

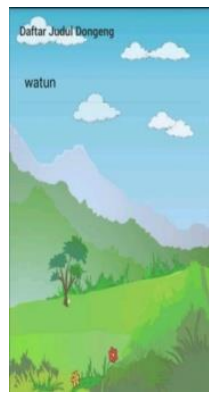

(f)

Gambar 3. a. Antar Muka Opening, b. Antar Muka Main Menu, c. Antar Muka List Dongeng, d. Antar Muka Output Baca Dongeng, e. Antar Muka Dongengku, f. Antar Muka List Dongengku

Adapun proses sistem yang terjadi pada saat teks dongeng dikonversikan ke suara pada aplikasi dongeng text to speech dapat dilihat sebagai berikut :

1. Tahap pertama adalah sistem membuat objek tts dari library google text to speech. dalam aplikasi ini digunakan dua objek tts yaitu untuk judul dan isi dongeng.

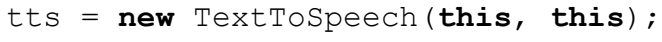

Gambar 4. Source code membuat objek 
2. Untuk mengkonversi teks menjadi suara digunakan sintak untuk penentuan bahasa yang akan digunakan pada saat text di conversi menjadi suara yang berlogat indonesia seperti Local("ind-IDN") yang bermaksud bahasa Indonesia, untuk lebih jelas dapat dilihat pada Gambar 5.

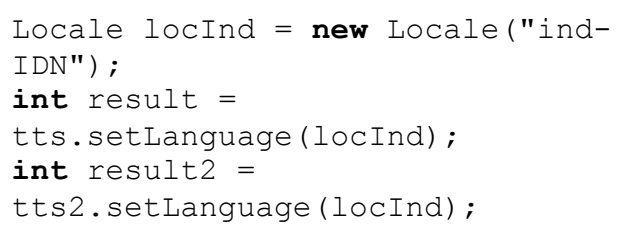

Gambar 5. Source Code Pengatuaran Bahasa

3. Kemudian Output yang dikeluarkan dari konversi berupa suara dimana sistem akan mendapatkan teks judu dan isi dongeng dari textview dan memanggil method speak untuk membaca judul dan isi.

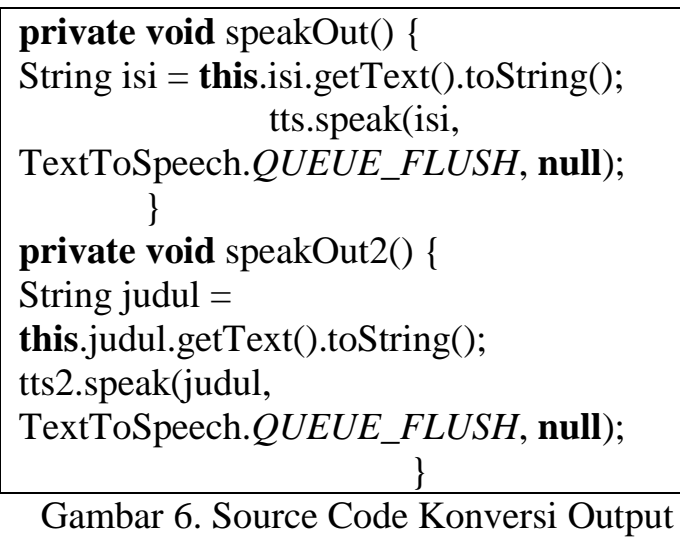

4. Pada saat activity di destroy, maka semua objek tts harus diberhentikan dan di shutdown.

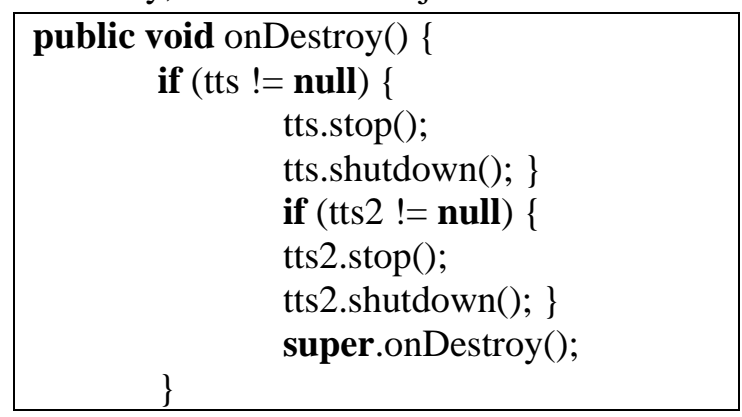

Gambar 7. Source Code memberhentikan pembacaan

\section{Hasil dan Pembahasan}

Pembahasan pada penelitian ini adalah dilakukan pengujian. Pengujian aplikasi juga diimplementasikan dengan menggunakan beberapa perangkat smartphone dengan sistem operasi android. Pengujiannya meliputi pengujian sistem, pengujian tata letak layout dan perbandingan antara aplikasi dongeng text to speech dengan aplikasi google terjemahan. 
Pengujian sistem meliputi pengujian aplikasi untuk menghasilkan keluaran suara dalam bahasa Indonesia secara online ataupun offline dan pengujian tata letak layout untuk mengetahui kesesuaian tampilan layout pada ukuran LCD yang berbeda.

Tabel 1 Pengujian Aplikasi Menggunakan Mobile Android Devices

\begin{tabular}{|c|c|c|c|c|c|c|c|}
\hline \multirow[t]{2}{*}{ No } & \multicolumn{4}{|c|}{ Spesifikasi Perangkat Android } & \multicolumn{2}{|c|}{$\begin{array}{c}\text { Pengujian } \\
\text { Sistem }\end{array}$} & \multirow{2}{*}{$\begin{array}{c}\text { Tata Letak } \\
\text { Layout }\end{array}$} \\
\hline & OS & CPU & RAM & LCD & online & offline & \\
\hline 1 & $\begin{array}{l}\text { Android 4.2.2 } \\
\text { Jelly Bean }\end{array}$ & $\begin{array}{l}\text { Dual Core } 1.2 \\
\mathrm{GHz}\end{array}$ & $\begin{array}{l}512 \\
\mathrm{MB}\end{array}$ & $\begin{array}{c}4 \\
\text { inch }\end{array}$ & $\sqrt{ }$ & - & Sesuai \\
\hline 2 & $\begin{array}{l}\text { Android 4.2.2 } \\
\text { Jelly Bean }\end{array}$ & $\begin{array}{l}\text { Dual Core } \\
1 \mathrm{GHz}\end{array}$ & $1 \mathrm{~GB}$ & $\begin{array}{c}4 \\
\text { inch }\end{array}$ & $\sqrt{ }$ & - & Sesuai \\
\hline 3 & $\begin{array}{l}\text { Android 5.1.1 } \\
\text { Lollipop }\end{array}$ & $\begin{array}{l}\text { Quad-core } 1.2 \\
\mathrm{GHz}\end{array}$ & $1 \mathrm{~GB}$ & $\begin{array}{c}5 \\
\text { inch }\end{array}$ & - & $\sqrt{ }$ & Sesuai \\
\hline 4 & $\begin{array}{l}\text { Android 4.4.2 } \\
\text { Kitkat }\end{array}$ & $\begin{array}{l}\text { Quad-core } \\
\text { Cortex A7 1,3 } \\
\text { GHz }\end{array}$ & $\begin{array}{l}512 \\
\mathrm{MB}\end{array}$ & 7,0 inch & $\sqrt{ }$ & - & $\begin{array}{l}\text { Tidak } \\
\text { Sesuai }\end{array}$ \\
\hline
\end{tabular}

Berdasarkan Tabel 1 dapat disimpulkan bahwa untuk hasil pengujian sistem pada perangkat android berhasil mengeluarkan keluaran suara bahasa Indonesia secara offline adalah perangkat android mulai versi 5.0.1 (Lollipop) dikarenakan pada perangkat tersebut sudah ada pengaturan bahasa text to speech untuk bahasa Indonesia. Sedangkan untuk perangkat android untuk versi Jelly Bean (4.2.2) harus digunakan secara online karena text to speech bahasa Indonesia tidak terinstall pada perangkat sehingga harus menghubungkan ke api google text to speech menggunakan internet.

Dan untuk hasil pengujian layout pada perangkat android adalah perangkat yang memiliki kesesuaian tampilan merupakan perangkat dengan ukuran LCD 4 sampai dengan 5 inci. Sedangkan perangkat yang memiliki ukuran LCD 7 inci keatas tampilan layout akan tampil berantakan tidak fleksibel.

Selain pengujian pada perangkat android aplikasi ini juga dilakukan perbandingan antara aplikasi dongeng text to speech dengan aplikasi google terjemahan, dimana keduanya memanfaatkan library google text to speech untuk menghasilkan keluaran suara. Perbandingan ini dilakukan dengan menggunakan perangkat android dengan spesifikasi perangkat yang sama yaitu menggunakan perangkat dengan sistem operasi android versi Lollipop (5.1.1). Perbandingan ini dilakukan untuk mengetahui efesiensi keluaran suara yang dihasilkan. Hasil perbandingan dapat dilihat pada Tabel 2.

Tabel 2 Perbandingan aplikasi

\begin{tabular}{|c|c|c|c|}
\hline & Kalimat & $\begin{array}{c}\text { Aplikasi Dongeng Text } \\
\text { To Speech }\end{array}$ & Aplikasi Google Terjemahan \\
\hline Waktu & Aplikasi Dongeng & $00: 00: 00.09$ & $00: 00: 01.33$ \\
\cline { 2 - 4 } Proses & Uswatun Hasanah & $00: 00: 00.13$ & $00: 00: 02.41$ \\
\hline
\end{tabular}

Berdasarkan Tabel 2 diatas, dapat diketahui bahwa perbandingan waktu proses sistem untuk mengeluarkan keluaran suara Aplikasi Dongeng Text To Speech lebih cepat mengeluarkan suara dari pada aplikasi google terjemahan. Dengan perbandingan untuk kalimat pertama Aplikasi Dongeng Text To Speech lebih cepat 1.24 detik daripada aplikasi google terjemahan, dan untuk kalimat kedua Aplikasi Dongeng Text To Speech lebih cepat 2.28 detik daripada aplikasi google terjemahan. Hal ini terjadi karena library google Text To Speech untuk 
aplikasi sudah ada pada atau sudah terinstal pada perangkat android, sedangkan untuk aplikasi google terjemahan harus koneksi internet dalam memanfaatkan library google Text To Speech sehingga kecepatan keluaran suaranya tergantung kecepatan internet pada perangkat android tersebut

\section{Kesimpulan}

Berdasarkan hasil dan pengujian terhadap penggunaan Aplikasi Dongeng Text to Speech sudah mampu membaca dongeng, walaupun dari segi intonasi suara belum alami sebagai mana manusia membaca dongeng, hal ini disebabkan karena intonasi pada dongeng text to speech hanya berdasarkan tanda baca.

Aplikasi Dongeng Text to Speech dapat berjalan dengan baik dan digunakan secara offline pada perangkat android mulai versi Lollipop (5.1.1). Dari segi tampilan aplikasi, aplikasi ini belum fleksibel sehingga hanya terlihat baik pada perangkat tertentu.Untuk pengembangan aplikasi dongeng text to speech diharapkan dapat mengatasi keterbatasan-keterbatasan tersebut, yaitu pengembangan library text to speech yang mendukung pembacaan dongeng dapat dilakukan sehingga output suaranya menjadi lebih alami. Serta tampilan aplikasi yang kompatible pada perangkat android yang memiliki ukuran LCD 7 inci keatas, sehingga bisa digunakan diberbagai ukuran perangkat android.

\section{Daftar Pustaka}

[1] Andayu, N.P., Perancangan Text to Speech Conveter Engine Dalam Pengucapan Kata Berbahasa Arab Sehari-hari, Jurnal Sistem dan Teknologi Informatika (JustIN), 2013,Universitas Tanjungpura, Tanjungpura, Vol: 3, No 1.

[2] Ardini, P.P, Pengaruh Dongeng dan Komunikasi Terhadap Perkembangan Moral Anak Usia 7-8 Tahun, Jurnal Pendidikan Anak, ., 2012, PAUD FID Universitas Negeri Gorontalo, Gorontalo.

[3] Pramadewi, P.M.M., Kesiman, M.W.A., 2013, Pengembangan Aplikasi Text to Speech untuk Bahasa Bali, Jurnal Nasional Pendidikan Teknik Informatika (JANAPATI), Universitas Pendidikan Ganesha Singaraja, Bali.

[4] Pressman, R.S. 2011. Software Engineering a Practitioner's Approach. $5^{\text {th }}$ Edition. Mc Graw Hill. New York - USA.

[5] Santoso, R.A., Surnaryono, D., dan Arieshanti, I, Rancangan Bangun Aplikasi Buku "Dongeng" - Kumpulan Cerita Rakyat Interaktif Berbasis iOS, Jurnal Teknik Pomits, ., 2013, Insitut Teknologi Sepuluh Nopember (ITS), Surabaya.

[6] Syafaat H, Nazruddin. 2015. Pemrograman Aplikasi Mobile Smartphone dan Tablet PC Berbasis Android Revisi Kedua. Informatika, Bandung. 